\title{
EVALUASI MATA KULIAH PIANO UNTUK MENGHASILKAN GURU MUSIK DI SEKOLAH
}

\author{
Diah Latifah \\ Jurusan Pendidikan Seni Musik UPI Bandung \\ Diah-singer@bdg.centrin.net.id
}

\begin{abstract}
Abstrak
Studi ini bertujuan untuk mengevaluasi mata kuliah instrumen pilihan wajib piano dan relevansinya terhadap tujuan kurikulum Jurusan Pendidikan Seni Musik Universitas Pendidikan Indonesia yang berkomitmen untuk menghasilkan pendidik musik profesional. Untuk memenuhi tuntutan ini, metode penelitian yang digunakan adalah studi kasus sosial inkuiri. Instrumen penelitian yang digunakan adalah pedoman observasi, pedoman wawancara, lembar pertanyaan lanjutan hasil informasi, dan kajian dokumen serta dokumentasi. Hasil Penelitian menyatakan bahwa partisipan mata kuliah ini belum mampu untuk mengggunakan piano sebagai pengantar pembelajaran musik umum. Informasi ini ditindaklanjuti dengan rekomendasi, penyempurnaan silabus dan implementasi pembelajaran mata kuliah instrumen pilihan wajib piano, seyogyanya dilengkapi dengan subyek penggunaan piano sebagai pengantar pembelajaran musik di sekolah.
\end{abstract}

Kata kunci: ketidaksesuaian kurikulum, evaluasi, rekomendasi 
Jurnal Penelitian dan Evaluasi Pendidikan

\title{
COURSE EVALUATION IN PIANO SUBJECT TO PRODUCE MUSIC TEACHERS IN SCHOOLS
}

\author{
Diah Latifah \\ Jurusan Pendidikan Seni Musik UPI Bandung \\ Diah-singer@bdg.centrin.net.id
}

\begin{abstract}
This study was aimed at evaluating "piano as compulsary course" and its relevancy toward the objectives of the curriculum of music education department of UPI that stated a commitment to provide proffesionals music educators. To meet this demand, the research methode used is Case Study In Social Inquiry. The research instruments are observation manual, interview manual, information question, and documentation. The research result shows that participants of this course have not shown capability of using piano as introduction to general music instruction. This information is followed up by the recommendations, syllabus improvements, and instruction implementation on the subject. It is recommended that "piano as compulsary course" is equiped with subject of piano usage as introduction of music instruction at schools.
\end{abstract}

Keywords: inappropiate curriculum, evaluation, recommendation 


\section{Pendahuluan}

Case Study in Social Inquiry merupakan model evaluasi kurikulum hasil buah pikir Robert E Stake. Case Study In Social Inquiry atau Studi Kasus Sosial Inkuiri, disamping model evaluasi, juga merupakan suatu metode penelitian evaluatif, yang memaknai suatu kasus yang terjadi dalam suatu program, khususnya program pendidikan atau program kurikulum. Model evaluasi ini memiliki keunggulan dalam kinerja evaluasi karena memiliki fleksibilitas tinggi, dengan kekhususan bernilai sosial. Kajian evaluasi yang diterapkan dalam model evaluasi ini, tidak dapat mengevaluasi suatu program dengan standardisasi yang memuat konten dengan makna generalisasi. Standar, dimaknai dengan komitmen pencapaian yang dapat digapai karakter kemanusiaan secara individual.

Khususnya dalam pendidikan seni, setiap personal memiliki bakat dan potensi dasar yang berlainan, komitmen pencapaian ditentukan, tetapi untuk menilai suatu proses pendidikan seni dan hasil pendidikan seni yang memuat sensitifitas rasa seni bagi setiap personal tidak mungkin digeneralisasikan. Komitmen pencapaian untuk hasil produk karya seni, bernilai estetik, bagi setiap orang berbeda. Misalkan, seorang pendidik seni membekali peserta didiknya dengan materi seni lukis dangan mazhab ekspresionisme. Mazhab ini memiliki beberapa ciri khusus untuk diterapkan dalam karya seni lukis, tetapi hasil lukisan setiap orang justru harus berbeda, untuk menunjukan kekuatan karakter dari rasa bahasa rupa yang dimiliki oleh setiap peserta didik. Demikian pula bagi pendidik seni musik, yang mengembangkan sensitifitas rasa musikal dalam bahasa bunyi. Sensitifitas rasa musikal dalam kemampuan seni musik diterjemahkan dalam kegiatan, bermain musik baik melalui instrumen musik atau vokal, menciptakan karya musik (compose music), mengaransir musik, dan kegiatan praktek musik lainya. Setiap individu yang bermusik, memiliki bakat dan talenta dengan keunikan masing masing. Ketika dua orang memainkan karya zaman atau mazhab klasik, misalnya sonata karya WA Mozart, kavau yang sama dan nomor yang sama, dengan pencapaian estetik yang telah menjadi komitmen secara internasional. Tapi kedua orang tersebut, harus memainkanya dengan berbeda sesuai dengan potensi dasar dan bakat 
musik masing-masing, meski masih dalam koridor hukum musik (agogig) karya zaman klasik yang dimainkan, karena pendidik musik yakin bagi anak kembarpun memiliki rasa musikal yang berbeda. Oleh karena ini, pendidikan musik sulit untuk digeneralisasikan, baik proses ataupun hasil.

Penelitian ini dilaksanakan karena terdapat gejala ketidaksesuaian produk hasil pembelajaran mata kuliah piano dengan tujuan kurikuler untuk menghasilkan guru musik umum di sekolah. Kasus-kasus dan isu-isu timbul, ketika pembelajaran mata kuliah instrumen pilihan wajib piano, di Jurusan Pendidikan Seni Musik UPI, bermasalah. Jurusan ini telah berkomitmen untuk menghasilkan tenaga pendidik dan kependidikan profesional. Para mahasiswa peserta mata kuliah ini, nampak belajar praktek estetik musik piano saja ketika implementasi pembelajaran piano dilaksanakan. Isu lain yang timbul, berdasar informasi para penguji Program Praktek Lapangan di sekolah, para mahasiswa yang telah lulus perkuliahan instrumen pilihan wajib piano, belum siap untuk mempergunakan piano atau alat musik keyboard sebagai pengantar pembelajaran musik umum di sekolah. Mereka belum siap mempergunakan piano sebagai media pembelajaran musik, ataupun piano sebagai alat evaluasi pada proses dan hasil pembelajaran musik umum di sekolah. Ketidaksiapan mahasiswa peserta mata kuliah bersangkutan, dapat diakibatkan oleh dosen pengampu yang kurang berkompeten membekali materi yang bernuansa pedagogi musik melalui piano, sarana dan prasarana belajar yang kurang atau dokumen kurikulum dalam hal ini silabus bermasalah. Tim pengajar mata kuliah ini dideteksi telah berkompeten untuk mengajar piano. Sarana dan prasarana juga telah mencukupi, banyak ruangan telah terisi piano, dan bahan perkuliahan pianopun telah mencukupi. Dengan fakta ini, peneliti mendeteksi kelemahan silabus dan proses pembelajaran mata kuliah bersangkutan untuk dievaluasi. Fokus permasalahan dapat dipaparkan dalam Gambar 1.

Kajian evaluatif utama yang dilaksanakan untuk mencari informasi mengenai relevansi mata kuliah instrumen pilihan wajib piano dalam menghasilkan calon guru musik di sekolah. 


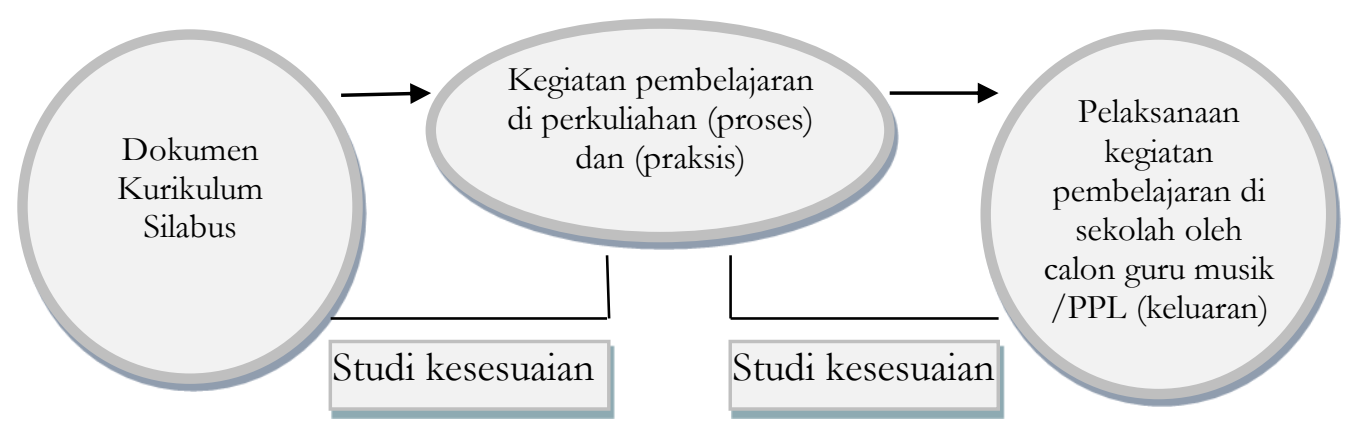

Gambar 1. Konteks Pendidikan Formal di Jurusan Pendidikan Seni Musik

\section{FPBS UPI}

Ketika ranah pendidikan dengan karakter seperti termaktub di atas, memiliki permasalahan, dan harus dievaluasi, model evaluasi yang sesuai harus diterapkan. Pendidikan dengan karakter ini tidak mungkin dievaluasi dengan model evaluasi yang berstandar ketat, tetapi dievaluasi dengan suatu model yang memiliki karakter khusus, yang dapat menarik informasi kelemahan dan keunggulan dari implementasi kurikuler yang dilaksanakan. Dengan alasan ini model evaluasi Case Study in Social Inquiry diaplikasikan.

\section{Metode Penelitian}

Metode penelitian yang diterapkan untuk mengevaluasi mata kuliah instrumen pilihan wajib piano adalah studi kasus, dengan nuansa sosial inkuiri. Studi kasus merupakan salah satu metode yang terhimpun dalam paradigma kulitatif. Hasan menyatakan (Hasan, 2008 : 7).

Kekuatan metodologi kualitatif yang memiliki validitas tinggi dalam menghasilkean data tentang proses, walaupun berlaku untuk suatu tempat tertentu, menjadi kekuatan metodologis para penganjur pendekatan kualitatif. Dampak hasil evaluasi kualitatif yang langsung dapat digunakan oleh subyek evaluasi menambah kekuatan pendekatan kualitatif dalam evaluasi kurikulum. Tokoh evaluasi seperti Stake yang dididik dalam tradisi kuantitatif yang kental berubah posisinya dan menjadi penganjur kuat bagi kelompok kualitatif. 
Studi Kasus Sosial Inkuiri memiliki kekuatan untuk menganalisis suatu kinerja evaluasi secara rinci, dan terkendali, karena terfokus pada satu kejadian evaluasi, bersifat faktual, serta bernuansa fenomenologis, mengaji berbagai kejadian sesuai apa adanya. Kajian penelitian studi kasus memberi makna yang lebih pada pemaknaan inti permasalahan secara lebih mendalam dan mendasar (grounded). Merriam mengungkapkan: (Merriam, 1998:26)

"Studi kasus, khususnya studi kasus kualitatif secara umum meliputi selurub wilayah pendidikan. Dari Wolcott's (1973) studi kasus klasik, manusia dalam pimpinan kantor, untuk mengkasuskan studi dari siswa-siswa, program, sekolah, guru, kebijakan, penelitian semacam ini telah menjelaskan praktek pendidikan selama tidak kurang dari tiga pulub tabun".

Kajian prinsip-prinsip pendidikan yang dievaluasi menekankan prinsip dasar dalam dimensi proses. Konteks pembelajaran dianalisis dalam konteks pendidikan formal terfokus pada kajian konten kurikulum yang diuji relevansinya. Untuk ini Stake menyatakan, dalam (Merriam, 1998:27):

"Stake (1994,1995), bagaimanapun, memfokuskan dan mencoba untuk menunjukekan dengan tepat unit dari studi - kasus". "Dalam edisi pertama dari buku ini, saya mendefinisikan studi kasus adalab produk akbir. Studi kasus kwalitatif adalah, intensif, deskripsi bolistik, dan analisis pada kejadian tunggal, fenomena, atau unit sosial" (Merriam, 1988:21). Wolcott (1992:36) juga memahami nya sebagai "produk akbir dari penelitian orientasi-lapangan dari pada metode atau strategi”.

Studi kasus dapat berkontribusi pada pemahaman yang bersifat umum (general), pada kejadian kejadian bersifat naturalistik. Kejadian atau hal-hal yang terjadi dapat dimaknai pada proses evaluasi mata kuliah instrumen pilihan wajib piano, dan untuk beberapa kasus dapat disimpulkan sebagai suatu studi naturalistik yang bersifat umum. Untuk ini Merriam kembali menyatakan" tentu saja setiap pendekatan ini menyatakan 
sesuatu tentang studi kasus yang berkontribusi pada pengertian umum (general), pada kealamiahan jenis penelitian".

Karena kebermaknaan dari studi kasus pada dunia pendidikan yang cukup menyeluruh, tujuan penelitian ini dapat dijangkau dengan cakupan kajian yang dilaksanakan.

Aliran fenomenologis saat ini banyak dipergunakan dan menjadi konsep utama dan metode sebagai landasan untuk melakukan suatu kegiatan, baik itu kegiatan penelitian atau kegiatan yang lain, misalkan dalam penelitian fenomenologis yang saat ini dilaksanakan, kegiatan evaluasi kurikulum instrumen pilihan wajib piano, Landman, 1971 menyatakan;

1. Fenomenologi sebagai metode yang dapat digambarkan sebagai aspek dari metodologi penelitian

2. Fenomenologi dalam fungsi: keterhubungan yang sangat bermakna dengan intisari dari rangkaian pelajaran pada pengajaran dan model pengajaranya.

Model evaluasi studi kasus Stake memiliki dasar pemikiran fenomenologis, berpusat pada satu lokal dan fenomena-fenomena yang terjadi dianalisis sesuai dengan lingkungan yang muncul dalam problematika orisinal. Seperti yang dinyatakan oleh Huserl dalam motto filosofisnya (Misiak , et al. 2009:16)," kembali pada berbagai hal itu sendiri"” ( $\mathrm{Zu}$ den Sachen Selbst). Penelitian ini dilaksanakan atas dasar kejadian dan atau kajian evaluasi kurikulum yang sebenarnya. Kebenaran ilmiah dari faham ini berdasarkan atas pengalaman yang sebenarnya, tidak terbias. Setiap kejadian berdasar fakta empirik atau emik dipaparkan secara rinci sesuai dengan kejadian apa adanya, tanpa rekayasa dan dikembalikan pada berbagai kejadian proses evaluasi kurikulum yang dilaksanakan.

Kajian fenomenologis dalam evaluasi kurikulum dinyatakan oleh Landman sebagai berikut:

Fenomenologi adalah unsur unsur signifikan dari penelitian kurikulum, khususnya desain kurikulum dan evaluasi kurikulum, sebagai intisari fenomenologis berupa kemungkinan eksistensi, dan fenomenologi adalah refleksi penghargaan pada struktur fundamental dari pengalaman. 
Studi kasus sosial inkuiri yang dikembangkan oleh Stake, mempunyai fungsi untuk mengevaluasi suatu proses aktifitas sosial yang mempunyai kaitan erat dengan proses pendidikan yang berlangsung dalam situasi sosial. Stake (Stake, 2009), memaknai evaluasi dalam konteks kinerja mengajar guru sebagai suatu proses, dengan pemaparan "Dengan "evaluasi" saya artikan: menjadi tahu kualitas dari tindakan, manfaat, dan kelemahan dari mengajar". Pernyataan Stake di atas memberi makna, bahwa hasil evaluasi bukanlah untuk penghakiman mutlak atas keterandalan suatu program kurikuler diimplementasikan, tetapi untuk mendapatkan informasi mengenai kelemahan dan keunggulan suatu kurikulum dilaksanakan. Penelitian ini dilaksanakan, untuk mendapatkan informasi kelemahan dan keunggulan implementasi kurikuler mata kuliah instrumen pilihan wajib piano.

Proses evaluasi mempergunakan model evaluasi Case Study in Social Inquiry yang telah disesuaikan dengan tujuan mengevaluasi mata kuliah instrumen pilihan wajib piano untuk menghasilkan calon guru musik di sekolah. Bagan model Evaluasi yang telah direvisi, dipergunakan untuk proses evaluasi sesuai tujuan penelitian disajikan pada Gambar 2.

Instrumen penelitian yang digunakan sebagai cara pengambilan informasi dilakukan dengan menggunakan instrumen penelitian; pedoman interview, pedoman observasi, pertanyaan-pertanyaan hasil informasi dari proses interview dan observasi (information question) yang hasilnya masih meragukan sebagai informasi hasil evaluasi sesuai tujuan evaluasi, dan dokumentasi melalui VCR.

Kajian dokumen, dilakukan dengan cara membandingkan setiap subyek silabus mata kuliah instrumen pilihan wajib piano, dengan tujuan kurikuler dari dokumen struktur kurikulum Jurusan Pendidikan Seni Musik, dalam Pengembangan Kurikulum Fakultas Pendidikan Bahasa dan Seni.

Alur kinerja evaluasi merupakan proses kinerja yang berupa siklus, dapat berawal dari irisan manapun yang terdapat pada core analysis evaluation (analisis evaluasi inti). Analisis evaluasi ini berupa lingkaran yang tergambarkan secara solid dan digambarkan sebagai empat irisan yang memuat irisan dokumen-dokumen kurikulum, irisan proses dan praksis dalam pembelajaran musik, praksis pembelajaran piano untuk 
memproduksi guru musik dan produknya merupakan guru musik umum. Seluruh irisan dikaji sesuai dengan kasus-kasus dan isu-isu yang terjadi.

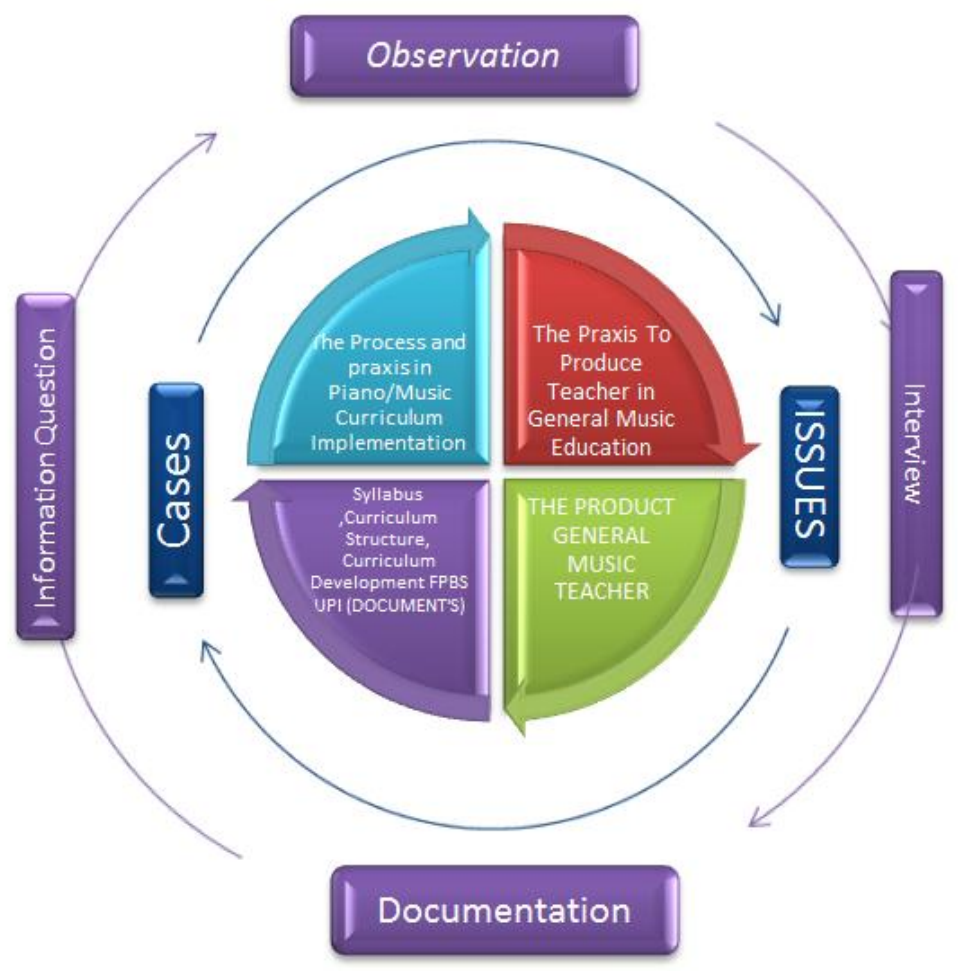

Gambar 2. Bagan Revisi Studi Kasus Sosial Inkuiri

\section{Hasil dan Pembahasan}

Hasil analisis data menyatakan Studi Kasus Sosial Inkuiri merupakan salah satu model evaluasi kurikulum yang berdimensi proses, memiliki pandangan dasar fenomenologis, bersifat apa adanya, berupa kejadian yang dianalisis kembali pada kejadian itu sendiri, bersifat naturalisitik, dan tidak dimungkinkan untuk membangun sebuah konklusi atau alur proses analisis yang merupakan sebuah rekayasa informasi dari hasil kajian evaluatif yang 
dilaksanakan. Proses kerja evaluasi model evaluasi ini, harus memaparkan peristiwa dan kejadian apa adanya, dipaparkan dengan jujur, sehingga seluruh kejadian dan kinerja dari evaluan (program kurikulum yang dilaksanakan) akan nampak secara jelas, dan proses perbaikan atau penyempurnaan implementasi, serta perbaikan dokumen kurikulum apabila diperlukan, berjalan dengan seharusnya sesuai dengan tujuan yang seharusnya dicapai oleh lembaga pendidikan bersangkutan.

Hasil evaluasi dokumen kurikulum diwakili silabus menyatakan, silabus mata kuliah instrumen pilihan wajib piano belum menggambarkan konten yang signifikan untuk mempersiapkan lulusanya sebagai calon guru musik, khususnya calon guru musik di sekolah. Gambaran dari silabus mata kuliah instrumen pilihan wajib piano, dipenuhi dengan pembekalan yang bersifat estetik, berupa penanaman ketrampilan baik secara praktikal atau konseptual, pada alur pola permainan piano secara estetis, serta pembekalan analisis musik sesuai style atau gaya karya musik piano yang dimainkan, dan menulis serta membuat pola iringan piano dengan alur melodi suatu karya musik. Silabus mata kuliah instrumen pilihan wajib piano memaksimalkan prinsip-prinsip materi pembelajaran piano yang beresensikan muatan estetika musik yang dibawakan melalui instrumen piano dalam konteks tradisi musik barat. Hal ini berkenaan dengan tereliminasinya beberapa mata kuliah akibat pemadatan jumlah sks yang ditempuh mahasiswa. Pada awal tahun 2005, konten satuan kredit semester yang dapat diambil mahasiswa berkisar antara 156 sks hingga 160 sks. Pengurangan kredit semester ini berpengaruh pada konten yang harus diambil mahasiswa, dan pemadatan atau pengurangan sks yang dilaksanakan lebih mengarah pada pembekalan konten didaktik pedagogi yang dilaksanakan melalui tindakan musikal atau pengalaman musik. Silabus mata kuliah instrumen pilihan wajib piano setelah dievaluasi memiliki kecacatan utama. Silabus mata kuliah instrumen pilihan wajib piano tidak membekali pesertanya sesuai dengan tujuan kurikulum Jurusan Pendidikan Seni Musik FPBS UPI. Silabus mata kuliah instrumen pilihan wajib piano hanya membekali pembekalan bidang aplikasi aspek estetik musik saja pada musik piano dengan tradisi musik barat. Pembekalan yang 
bersifat pedagogis untuk mempersiapkan lulusan mata kuliah instrumen pilihan wajib piano sebagai calon guru musik di sekolah belum nampak

Hasil evaluasi implementasi pembelajaran mata kuliah instrumen pilihan wajib piano memaknai memberikan pembekalan materi yang memiliki esensi pengembangan estetika musik berupa kecakapan dan kemahiran aspek-aspek pianistik dan interpretasi serta ekspresi untuk bermain karya musik melalui piano sesuai hukum-hukum musik yang berlaku. Materi lain yang diberikan selain pembekalan seperti materi yang tersebut di atas adalah materi sight reading merupakan pembekalan kecakapan refleksi membaca notasi musik sesuai tanda-tanda ekspresi dan tempo yang terdapat dalam musik yang bersangkutan. Pola iringan juga merupakan suatu materi yang diberikan untuk memperluas kecakapan pengembangan estetika musik melalui piano untuk lebih mengembangkan teknik-teknik yang diperlukan mahasiswa ketika mahasiswa harus mengiringi sebuah melodi baik yang dilakukan melalui vokal manusia, instrumen musik lain selain piano, bentuk musik chamber musik. Komponen-komponen pembelajaran musik umum melalui piano belum dibekalkan kepada mahasiswa, kecuali mempersiapkan mahasiswa menjadi guru piano tingkat anak-anak, tetapi pada tahun 2009, materi ini sudah tidak dibekalkan lagi, karena komitmen beberapa dosen menganggap bahwa pemantapan materi estetik jauh lebih bermakna bagi mahasiswa dari pada materi komponen-komponen pembelajaran musik umum yang disampaikan melalui piano untuk mengajar di sekolah. Aplikasi ini, akibat dari perubahan kebijakan pemerintah yang di ajukan pada tahun 2005, tentang perubahan kurikulum Lembaga Pendidikan Tenaga Keguruan yang mengalami pemadatan konten.

Pendekatan dan metode pembelajaran yang dilaksanakan oleh para dosen pengampu, menguatkan kompetensi musikal, dan mengembangkan kepiawaian mahasiswa untuk benar benar cakap memainkan piano, sesuai etude dan karya musik yang telah disepakati, disamping ketrampilan tangga nada, trinada, arpegio, kadens dan latihan penjarian sejenis untuk menguatkan rasa aliran musik serta kelenturan dan kekuatan jari. Selain kompetensi di atas, mahasiswa juga dibekali dengan kompetensi memainkan iringan, semuanya diberikan melalui pendekatan learning by doing 
(belajar melalui pengalaman musik), serta meningkatkan kompetensi dengan proses konstruktivistik dan kreatif pada saat menyusun pola iringan karya musik. Aspek pendekatan pembelajaran sendiri hanya merupakan aktivitas guru pada mahasiswa, tetapi pola pendekatan pembelajaran musik umum melalui piano sebagai materi ajar, belum pernah dibekalkan sebagai materi pada mahasiswa. Metode pembelajaran yang digunakan bervariasi, dari ceramah, tanya jawab mengenai materi yang diberikan, demonstrasi dan praktek bermain piano, imitasi, resitasi materi yang akan dimainkan pada pertemuan selanjutnya, dan teknik eksplorasi digunakan saat mahasiswa mencoba untuk menyusun pola iringan. Metode pembelajaran musik umum melalui piano sebagai materi ajar, dan piano sebagai media pembelajaran musik umum yang diberikan sebagai materi ajar belum pernah dibekalkan kepada mahasiswa.

Proses evaluasi dilaksanakan dalam dua teknik. Evaluasi hasil pembelajaran dan proses pembelajaran piano. Evaluasi proses dilaksanakan setiap awal dan akhir pertemuan, terdeteksi ketika para dosen meminta para mahasiswa untuk memulai suatu satuan pembelajaran pada kegiatan awal, dengan mengulas hasil pembelajaran minggu sebelumnya, dan meminta mahasiswa untuk mempraktekan tugas yang diberikan pada minggu sebelumnya, untuk memaknai pada fase mana dalam pelanjutan estetik musik pada piano, aspek apa yang harus dikembangkan atau disempurnakan, sebgai penentuan ketika para dosen melangkah pada materi inti. Hasil observasi ini, memberikan suatu informai bahwa setiap dosen pengampu mata kuliah memberikan evaluasi proses.

Evaluasi hasil diberikan saat Ujian Akhir Semester dilaksanakan. Ujian akhir semester dilaksanakan dengan kriteria materi ujian sebagai berikut: Materi pertama adalah materi yang berupa penguasaan kecakapan kelenturan, kekuatan dan touch penjarian pada kegiatan praktek tangga nada, trinada pendek dan panjang, arpegio, arpegio dominant septim, tangga nada chromatis, tangga nada poli ritmik, dan kadens dalam tiga posisi yang dimainkan pada seluruh tonalitas baik mayor atau minor, bertahap atau pre rekuisit sesuai grade yang dilalui mahasiswa. Materi kedua, mahasiswa diminta untuk memainkan karya musik pada piano dalam tiga style, yaitu style Barok, Klasik dan Romantik, Modern atau Kontemporer. Mahasiswa 
diharuskan mampu menterjemahkan bahasa musik sesuai gramatikal musik barat dalam style atau genrenya. Materi ketiga adalah penguasaan dan kecakapan sight reading. Sight reading test diberikan kepada mahasiswa sesuai grade yang dilalui mahasiswa. Evaluasi ini benar benar merupakan evaluasi hasil, meski pada akhirnya, tahapan kemajuan yang diperoleh mahasiswa saat proses perkuliahan juga memiliki dampak khusus pada hasil evaluasi, yang disesuaikan dengan kemajuan yang dicapai mahasiswa.

Para dosen pengampu cukup memahami potensi peserta didik, meski setiap dosen memiliki ciri khusus untuk mengembangkan mahasiswanya, sesuai dengan potensi pribadi para dosen. Terdapat dosen yang mengembangkan potensi untuk mengolah esensi musik sebagai pola iringan dan aransemen, juga terdapat dosen yang piawai untuk mengembangkan potensi mahasiswa memainkan karya musik piano, sesuai style dan genrenya.

Para dosen pengampu rata-rata memiliki kemampuan untuk menyusun rencana pembelajaran mata kuliah piano, meski terkesan setiap dosen memiliki karakter perencanaan yang disesuaikan dengan keahlian dan kepiawaian dosen-dosen bersangkutan. Aspek ini seyogyanya dicermati dan dikonsolidasikan, untuk menyusun acuan perencanaan yang seimbang, mengingat tujuan kurikuler kurikulum jurusan pendidikan seni musik untuk menghasilkan tenaga pendidik dan kependidikan musik berkompeten.

Kelulusan PPL mahasiswa yang telah lulus mata kuliah instrumen pilihan wajib piano, bukan berarti tanpa kelemahan atau kecacatan. Dalam disiplin ilmu keguruan musik, kemapanan penguasaan materi domain musik dan keguruan, baik teoritis dan praktis harus seimbang, saling menguatkan dan mendukung. Kelemahan yang nampak bagi lulusan mata kuliah instrumen pilihan wajib piano adalah tidak tereksposnya alat musik keyboard, yang dipergunakan sebagai pengantar pembelajaran musik, atau media dan alat pembelajaran musik, meski di SMA Pasundan III Bandung (tempat pengumpulan data saat penelitian ini dilaksanakan) memiliki instrumen musik keyboard. Ketidakbiasaan mahasiswa lulusan mata kuliah instrumen pilihan wajib piano mempergunakan alat musik keyboard sebagai alat dan media pembelajaran musik nampak ketika mereka menjalani ujian praktek mengajar dalam Program Praktek Lapangan, tidak satupun dari 
mereka memilih untuk mempergunakan alat keyboard, tetapi memilih untuk mempergunakan benda benda di sekitar lingkungan sebagai sumber bunyi untuk membelajarkan siswa mereka, agar berkompeten untuk bermain musik dalam konteks struktur musik yang paling sederhana. Mahasiswa Nampak canggung mempergunakan alat keyboard sebagai media pembelajaran musik umum di sekolah. Beberapa mahasiswa menghadapi kecanggungan ketika harus mempergunakan alat keyboard sebagai media untuk memperkenalkan prinsip dasar praktek musik, seperti birama, tonalitas, pola irama, bentuk dan struktur lagu, progresi akor, dan lainya. Mereka mampu tetapi nampak tersendat, dan beberapa kali mengalami kesulitan menerapkan pembelajaran, untuk menyampaikan materi musik umum melalui keyboard.

\section{Simpulan}

Setelah proses evaluasi dilaksanakan, kecacatan utama terdapat pada silabus, sehingga terjadi proses berantai yang sesuai dengan acuan silabus. Silabus tidak memuat konten komponen pembelajaran musik umum yang dilaksanakan melalui praktek piano, secara umum proses pembelajaran yang dilaksanakan para dosen pengampu mata kuliah piano juga tidak mempersiapkan mahasiswanya sebagai calon guru musik umum, yang dibekali dengan materi pedagogi musik umum melalui piano.

Proses pembelajaran mata kuliah instrumen pilihan wajib piano sesuai dengan komitmen dalam silabus. Para pengampu mata kuliah ini mengimplementasikan konten dalam silabus dengan baik, dan ini berarti mata kuliah instrumen pilihan wajib piano belum memuat pembekalan yang bersifat pedagogis, untuk mempersiapkan pesertanya mampu mengantarkan materi pembelajaran musik di sekolah yang disampaikan melalui piano. Produk perkuliahan mata kuliah instrumen pilihan wajib piano, sesuai dengan penggambaran yang terdapat pada konten silabus dan proses pembelajaran yang dilaksanakan. Para lulusan mata kuliah instrumen pilihan wajib piano, cukup berkompeten untuk memainkan karya karya musik piano dalam berbagai zaman dan style dalam tradisi musik barat, baik karya zaman Barok, zaman Klasik, zaman Romantik, karya modern atau 
kontemporer. Beberapa diantara mereka juga telah mampu mengiringi atau membuat pola iringan lagu-lagu dengan taraf kesulitan tertentu sesuai grade para lulusan. Tetapi tatkala para lulusan diminta untuk mempergunakan piano sebagai pengantar pembelajaran musik di sekolah, mereka terasa kikuk dan bahkan amat sulit untuk menerapkanya. Misalkan, mereka diminta oleh dosen penguji Program Praktek Lapangan di sekolah, untuk mempergunakan piano sebagai pengantar materi pembelajaran musik barat, misalkan materi ilmu melodi dalam tonal barat, para lulusan mata kuliah ini masih mengalami kesulitan untuk menerapkanya.

Secara umum, mahasiswa yang berkomitmen pada mata kuliah instrumen pilihan wajib piano, mampu mempresentasikan karya musik piano dengan baik sesuai tradisi musik barat serta mampu menerapkan rasa musikal melalui etude, latihan keluwesan penguatan jari dan melalui kegiatan bermain tangga nada, trinada, arpegio, arpegio dominan septim, tangga nada kromatis, kadens pada posisi lengkap serta beberapa variasi memainkan tangga nada dalam berbagai tonalitas sesuai dengan konten silabus. Ironisnya pada saat mereka harus mengajar musik umum di sekolah, para lulusan mata kuliah instrumen pilihan wajib piano sangat jarang menggunakan alat musik keyboard untuk membantu mereka dalam proses pembelajaran musik umum di sekolah, dan mahasiswa terasa masih belum akrab dengan alat musik ini ketika harus dipergunakan sebagai alat dan media pembelajaran musik umum di sekolah. Mahasiswa tidak mempergunakan alat musik keyboard karena memang belum pernah diajarkan bagaimana menerapkan alat musik ini dalam proses pembelajaran di kelas-kelas musik umum di sekolah. Padahal alat musik keyboard, diantaranya piano, memiliki keunggulan untuk diterapkan sebagai pengantar pembelajaran musik umum di sekolah. Alat keyboard sangat baik untuk dipergunakan sebagai media pembelajaran musik, dan alat evaluasi pembelajaran musik umum. Alat keyboard atau piano efisien dipergunakan sebagai alat untuk mengajar sensitifitas rasa musik, misalnya menanamkan aspek kepekaan pendengaran untuk mengidentifikasi bahasa bunyi dalam jajaran nada dodekatonis, menanamkan rasa tonal, menanamkan rasa harmoni, memperkenalkann bentuk dan struktur lagu dalam sistem tonal barat, pengenalan rasa ritmik, dan alat yang baik untuk memahami potensi 
dasar peserta didik dalam musik. Ketika masuk kelas alat ini tidak perlu disetem seperti pada gitar atau alat gesek, jangkauan dan luas wilayah nada cukup luas untuk memahami jangkauan nada peserta didik ketika membawakan karya musik vokal, disamping itu untuk memainkannya sebagai media dan alat belajar musik umum tidak memerlukan teknik tinggi seperti seseorang yang mempelajari piano sebagai seorang pianis.

Rekomendasi untuk mengantisipasi ketidaksiapan mahasiswa mempergunakan alat keyboard sebagai pengantar, media dan alat evaluasi pada pembelajaran musik umum di sekolah adalah, konten silabus harus direvisi. Diperlukan penambahan pembekalan komponen-komponen pembelajaran musik yang dapat dilaksanakan melalui alat musik keyboard atau piano, disela-sela pembekalan aspek estetik pada konten silabus mata kuliah instrumen pilihan wajib piano. Misalkan, konten silabus instrumen pilihan wajib piano, selain diberikan materi tangga nada pada berbagai tonalitas baik mayor dan minor, karya empat zaman atau style, trinada panjang dan pendek serta kadens posisi lengkap sesuai tangga nada yang dimainkan, dibekalkan juga bagaimana cara menggunakan alat musik keyboard atau piano sebagai pengantar materi pembelajaran musik di sekolah.

Materi materi pembelajaran piano yang telah terbukti unggul dan membekali mahasiswanya dengan kompetensi tinggi dalam penyajian musik piano dengan nilai estetik yang baik, harus dipertahankan. Perlu reorganisasi konten dalam silabus secara bijaksana, agar seluruh tujuan pendidikan musik tercapai, baik mempersiapkan lulusanya sebagai penyaji musik bermutu melalui piano, sekaligus sebagai guru musik profesional.

Proses pembelajaran yang dilaksanakan sudah seharusnya berkomitmen dengan acuan yang telah digambarkan konten silabus, sehingga tujuan jurusan Pendidikan Seni Musik UPI untuk memproduksi calon guru musik profesional dapat tercapai. Kesepakatan setiap dosen pengampu mata kuliah ini untuk memproduksi penyaji musik piano dan calon guru musik profesional harus diperkuat, demi mencapai visi dan misi Jurusan Pendidikan Seni Musik UPI untuk memproduksi tenaga pendidik dan kependidikan musik profesional yang berkompeten dan memiliki 
keunggulan untuk mengimplementasikan kompetensinya dilapangan sebagai tenaga ahli bidang musik.

\section{Daftar Pustaka}

Hasan, H S. 2008. Evaluasi Kurikulum. Bandung: Remaja Rosda Karya

Landman. 1971. Phenomenoligical Method. Dimabil pada tanggal 14 Maret 2011 dari http://georgeyonge.net/sites/georgeyonge.net/files/Landman \%20 Phen method.pdf)

Merriam, Sharan B., 1998. Qualitative Research and Case Study Applications in Education, California: Jossey-Bass Publisher

Misiak, Henryk. Et al. Psikologi, Fenomenologi, Eksistensial, dan Humanistik. Bandung: Refika Tama

Stake, R E. Case Study. Tersedia Dalam (http://www.unkassel.de/fb5/kigg/dateien/Stake, $\% 20$ case $\% 20$ studi $^{\circ}$ es.pdf) 